\title{
CASP8 and FADD-Like Apoptosis Regulator
}

National Cancer Institute

\section{Source}

National Cancer Institute. CASP8 and FADD-Like Apoptosis Regulator. NCI Thesaurus.

Code C96018.

CASP8 and FADD-like apoptosis regulator ( $480 \mathrm{aa}, \sim 55 \mathrm{kDa}$ ) is encoded by the human CFLAR gene. This protein plays a role in the inhibition of caspase-dependent apoptosis. 